Research article Open Access

\title{
Vitamin D receptor gene BsmI polymorphisms in Thai patients with systemic lupus erythematosus
}

\author{
Wilaiporn Sakulpipatsin1, Oravan Verasertniyom², Kanokrat Nantiruj ${ }^{1}$, Kitti Totemchokchyakarn¹, \\ Porntawee Lertsrisatit ${ }^{1}$ and Suchela Janwityanujit ${ }^{1}$
}

\author{
1Division of Allergy, Immunology and Rheumatology, Department of Medicine, Faculty of Medicine, Ramathibodi Hospital, Mahidol University, Rama \\ 6 Road, Bangkok10400, Thailand \\ ${ }^{2}$ Research Center, Department of Medicine, Faculty of Medicine, Ramathibodi Hospital, Mahidol University, Rama 6 Road, Bangkok 10400, Thailand \\ Corresponding author: Suchela Janwityanujit, rasjw@mahidol.ac.th
}

Received: 15 Sep 2005 Revisions requested: 13 Oct 2005 Revisions received: 31 Jan 2006 Accepted: 31 Jan 2006 Published: 20 Feb 2006

Arthritis Research \& Therapy 2006, 8:R48 (doi:10.1186/ar1910)

This article is online at: http://arthritis-research.com/content/8/2/R48

(C) 2006 Sakulpipatsin et al.; licensee BioMed Central Ltd.

This is an open access article distributed under the terms of the Creative Commons Attribution License (http://creativecommons.org/licenses/by/2.0), which permits unrestricted use, distribution, and reproduction in any medium, provided the original work is properly cited.

\begin{abstract}
The immunomodulatory role of 1,25-dihydroxyvitamin D3 is well known. An association between vitamin D receptor (VDR) gene $\mathrm{Bsm} /$ polymorphisms and systemic lupus erythematosus (SLE) has been reported. To examine the characteristics of VDR gene $B s m /$ polymorphisms in patients with SLE and the relationship of polymorphisms to the susceptibility and clinical manifestations of SLE, VDR genotypings of 101 Thai patients with SLE and 194 healthy controls were performed based on polymerase chain reaction-restriction fragment length polymorphism (PCR-RFLP). The relationship between VDR gene Bsm/ polymorphisms and clinical manifestations of SLE was evaluated. The distribution of VDR genotyping in patients
\end{abstract}

with SLE was $1.9 \%$ for BB (non-excisable allele homozygote), $21.78 \%$ for $\mathrm{Bb}$ (heterozygote), and $76.23 \%$ for bb (excisable allele homozygote). The distribution of VDR genotyping in the control group was $1.03 \%$ for BB, $15.98 \%$ for $\mathrm{Bb}$, and $82.99 \%$ for bb. There was no statistically significant difference between the two groups $(p=0.357)$. The allelic distribution of $B$ and $b$ was similar within the groups $(p=0.173)$. The relationship between VDR genotype and clinical manifestation or laboratory profiles of SLE also cannot be statistically demonstrated. In conclusion, we cannot verify any association between VDR gene Bsm/ polymorphism and SLE. A larger study examining other VDR gene polymorphisms is proposed.

\section{Introduction}

The importance of genetic influences on systemic lupus erythematosus (SLE) has been recognized through cumulative genetic epidemiologic studies. Many population-based studies have shown associations between the disease and alleles of immunologically relevant genes, including certain major histocompatibility complex (MHC) loci, Fc $\gamma$ receptor, and cytokines [1]. 1,25-dihydroxyvitamin D3 is thought to exert many of its action through interaction with a specific intracellular receptor. At the molecular level, 1,25-dihydroxyvitamin D3 inhibits the accumulation of mRNA for interleukin (IL)-2, interferon (IFN)- $\gamma$, and granulocyte-macrophage colony-stimulating factor (GM-CSF). At the cellular level, the hormone interferes with Thelper cell (Th) function, reducing Th induction of immunoglobulin production by $\mathrm{B}$ cells. When given in vivo, 1,25dihydroxyvitamin D3 has been particularly effective in prevention of autoimmune diseases such as experimental autoim- mune encephalitis and murine lupus [2]. It has been demonstrated that patients with SLE have a lower level of 25 hydroxyvitamin D3 than do healthy controls [3]. In addition, high-dose 1,25-dihydroxyvitamin D3 and its analog may be useful therapeutic agents for psoriatic arthritis [4] and rheumatoid arthritis [5].

Polymorphism of the vitamin D receptor (VDR) gene was found to be associated with many diseases, including osteoporosis [6], hyperparathyroidism [7], and prostate cancer [8]. An association between VDR gene polymorphism and SLE in Japanese and Chinese patients has been reported with mixed results [9-11]. Although Asians are closely related ethnically, the genetic admixture in Japan or China is different from that of Thailand. Because a high prevalence and high clinical severity of SLE are also observed in the Thai population, we examined the characteristics of VDR gene $B s m /$ polymorphisms in

$\mathrm{bb}=$ excisable allele homozygote; $\mathrm{Bb}=$ heterozygote; $\mathrm{BB}=$ non-excisable allele homozygote; $\mathrm{HWE}=$ Hardy-Weinberg equilibrium; IFN = interferon; $\mathrm{IL}=$ interleukin; $\mathrm{SLE}=$ systemic lupus erythematosus; $\mathrm{Th}=\mathrm{T}$ helper cell; $\mathrm{VDR}=$ vitamin $\mathrm{D}$ receptor. 
Table 1

Distribution of VDR genotyping in patients with SLE and healthy controls

\begin{tabular}{|c|c|c|c|}
\hline & \multicolumn{3}{|c|}{ VDR genotype } \\
\hline & BB & $\mathrm{Bb}$ & $\mathrm{bb}$ \\
\hline SLE, $n=101(\%)$ & $2(1.9)$ & $22(21.78)$ & 77 (76.23) \\
\hline Control, $n=194(\%)$ & $2(1.03)$ & 31 (15.98) & 161 (82.99) \\
\hline \multicolumn{4}{|c|}{$\begin{array}{l}\chi^{2} \text { test }=2.062, p=0.357 . \text { Hardy-Weinberg equilibrium test: } \chi^{2}= \\
0.08, p=0.77 \text { in patients and } \chi^{2}=0.14, p=0.71 \text { in controls. bb }= \\
\text { excisable allele homozygote; } B b=\text { heterozygote; } B B=\text { non-excisable } \\
\text { allele homozygote; SLE, systemic lupus erythematosus; VDR, vitamin } \\
D \text { receptor. }\end{array}$} \\
\hline
\end{tabular}

a larger cohort of Thai patients with SLE and the relationship of polymorphisms to the susceptibility and clinical manifestations of SLE.

\section{Materials and methods}

This study was conducted in accordance with the principles embodied in the Declaration of Helsinki and was approved by the ethical committees of the Ramathibodi Hospital, Mahidol University, Bangkok, Thailand. DNA from 101 patients with SLE was examined. All patients fulfilled the 1982 revised criteria for SLE [12]. All were females older than 15 years of age. They did not meet criteria for other autoimmune diseases. DNA from 194 unrelated healthy subjects served as controls. All healthy subjects were females older than 15 years of age. VDR genotyping was performed by polymerase chain reaction-restriction fragment length polymorphism (PCR-RFLP).

Genomic DNA was extracted from peripheral white blood cells using standard phenol-chloroform method. PCR was carried out in a final reaction volume of $50 \mu$ l. Oligonucleotide primers designed to anneal to exon 7 (primer 1, 5' CAACCAAGACTACAAGTACCGCGTCAGTGA-3') and intron 8 (primer 2, 5'AACCAGCGGGAAGAGGTCAAGGG-3') were used to amplify 825 bp fragment, including the polymorphic $B s m /$ site in intron 7 of the gene. The following reagents were added to a 200- $\mu$ l ultramicrocentrifuge tube: $5 \mu$ of $10 \times$ buffer $(100$ $\mathrm{mM}$ Tris $\mathrm{HCl} \mathrm{pH} \mathrm{9.0,500} \mathrm{mM} \mathrm{KCl,} \mathrm{and} \mathrm{1.0 \%} \mathrm{Triton} \mathrm{x}-100), 2$ $\mu \mathrm{l}$ of $\mathrm{MgCl}_{2}(25 \mathrm{mM}), 3 \mu \mathrm{l}$ of deoxynucleotide triphosphate (2 $\mathrm{mM}$ each) (Promega, Madison, WI, USA), $0.5 \mu$ of primer 1 $(20 \mu \mathrm{M}), 0.5 \mu \mathrm{l}$ of primer $2(20 \mu \mathrm{M}), 2.5$ units of Taq DNA polymerase (Promega), $300 \mathrm{ng}$ of template DNA, and water to a final volume of $50 \mu \mathrm{l}$.

The cycling condition was set as follows: one cycle at $95^{\circ} \mathrm{C}$ for 3 minutes, 30 cycles at $95^{\circ} \mathrm{C}$ for 30 seconds, $56^{\circ} \mathrm{C}$ for 30 seconds, and $72^{\circ} \mathrm{C}$ for 30 seconds. One final cycle of the extension was performed at $72^{\circ} \mathrm{C}$ for 10 minutes.

One microliter of the PCR product was digested at $65^{\circ} \mathrm{C}$ for 1 hour in the final volume of $10 \mu \mathrm{l}$ with 5 units of restriction
Table 2

VDR allelic frequency in patients with SLE and healthy controls

\begin{tabular}{lcc}
\hline & $\mathrm{B}$ & $\mathrm{b}$ \\
\hline SLE, $n=101(\%)$ & $26(12.87)$ & $176(87.12)$ \\
Control, $n=194(\%)$ & $35(9.02)$ & $353(90.98)$ \\
\hline$\chi^{2}$ test $=2.125, p=0.145$. b, excisable allele; B, non-excisable \\
allele; SLE, systemic lupus erythematosus; VDR, vitamin D receptor.
\end{tabular}

enzyme Bsml (New England Biolabs Inc., Ipswich, MA, USA) in $1 \times$ buffer. The digested samples were fractionated by electrophoresis in a 1.5\% agarose gel. Restriction fragments were detected by staining with ethidium bromide, and genotypes were determined by comparing the restriction length polymorphism band patterns with a $100 \mathrm{bp}$ DNA ladder run on the same gel. The presence of the Bsml restriction site generated $175 \mathrm{bp}$ and $650 \mathrm{bp}$ fragments, whereas the absence of this site yielded an 825 bp fragment.

The genotypes were classified as excisable allele homozygote (bb), non-excisable allele homozygote (BB), and heterozygote (Bb).

\section{Statistical analysis}

Analyses were performed with Epi Info ${ }^{\mathrm{TM}} 2002$ Results from patients with SLE and control subjects were compared using the $\chi^{2}$ test for statistical significance. Hardy-Weinberg equilibrium (HWE) was determined by Pearson's $\chi^{2}$ goodness-of-fit test.

\section{Results}

The distribution of VDR genotyping in patients with SLE was $1.9 \%$ for $\mathrm{BB}, 21.78 \%$ for $\mathrm{Bb}$, and $76.23 \%$ for bb. The distribution of VDR genotyping in the control group was $1.03 \%$ for $\mathrm{BB}, 15.98 \%$ for $\mathrm{Bb}$, and $82.99 \%$ for bb. There was no statistically significance difference between the two groups ( $p=$ 0.357) (Table 1). The genotype frequencies were consistent with HWE in patients and controls $\left(\chi^{2}=0.08, p=0.77\right.$ and $\chi^{2}$ $=0.14, p=0.71$, respectively). The allelic distribution of $B$ and b was similar within the two groups $(p=0.173)$ (Table 2$)$. The relationship between VDR genotype and clinical manifestation or laboratory profiles of SLE cannot be statistically demonstrated (Table 3).

\section{Dicussion}

Most tissues in the body, including heart, stomach, pancreas, bone, skin, gonads, and activated T and B lymphocytes, have the nuclear receptor for 1,25-dihydroxyvitamin D3 (VDR). Thus, it is not surprising that 1,25-dihydroxyvitamin D3 has a multitude of biologic effects that are non-calcemic in nature [13]. Recent research shows that the biologic action of vitamin $D$ extends well beyond the classic function to include effects on immunity, muscle and vasculature, reproduction, and the growth and differentiation of many cell types [14]. 1,25-Dihy- 
droxyvitamin D3 directly inhibits synthesis and secretion of IL$2[15,16]$ and IFN- $\gamma[17,18]$ and also inhibits immunoglobulin production [19]. Genomic actions of 1,25-dihydroxyvitamin D3 are mediated through its nuclear receptor (VDR). The VDR regulates gene transcription by binding to the hexameric core binding motif in promoter region of target genes, VDR element (VDRE) [17]. Extensive studies focused on this VDR gene in various phenotypes have revealed the association between VDR polymorphism and many non-skeletal diseases [20].

Although SLE has features consistent with Th2-type cytokine predominance, both Th1 and Th2 cytokine may be involved in the pathogenesis of SLE [21]. Mononuclear cells of patients with SLE have defects in IL-2 signal transduction and decreased production of IFN- $\gamma$ [22]. IFN- $\gamma$, tumor necrosis factor (TNF)- $\alpha$, and IL-1 are the most important adhesion molecules inducing cytokine, and they increase in autoimmune renal disease, particularly in Mrl/lpr-Fas and NZB/W mice [23].

Recently, VDR gene $B s m /$ polymorphisms have been used as genetic markers to determine their association with SLE [911]. A Japanese study of 58 patients with SLE found that the BB genotype might trigger the development of SLE and that the bb genotype was associated with lupus nephritis [9]. A Taiwanese study[10] of 47 Chinese patients with SLE also found an increased distribution of the VDR BB genotype in SLE but indicated no association between the frequency of VDR allelic variations and clinical manifestations or laboratory profiles. In our study, the BB genotype is low in both 194 healthy controls and 101 patients with SLE. However, this is in accordance with previous findings in the Thai population [24]. Thailand is geographically situated in an area between China and India. This genetic admixture may influence the distribution of VDR gene polymorphism. We cannot demonstrate

Table 3

Relationship between VDR genotype and clinical manifestation or laboratory profiles of SLE

\begin{tabular}{|c|c|c|c|c|}
\hline & BB $\%$ (ratio) $n=2$ & $\mathrm{Bb} \%$ (ratio) $n=22$ & bb $\%$ (ratio) $n=77$ & Total \% (ratio) \\
\hline Malar rash & $50(1 / 2)$ & $54.54(12 / 22)$ & $54.54(42 / 77)$ & $54.45(55 / 101)$ \\
\hline Discoid rash & $0(0 / 2)$ & $27.27(6 / 22)$ & $31.16(24 / 77)$ & $29.70(30 / 101)$ \\
\hline Photosensitivity & $50(1 / 2)$ & $31.81(7 / 22)$ & $38.96(30 / 77)$ & $37.62(38 / 101)$ \\
\hline Oral ulcer & $50(1 / 2)$ & $31.81(7 / 22)$ & $36.36(28 / 77)$ & $35.64(36 / 101)$ \\
\hline Arthritis & $100(2 / 2)$ & $77.27(17 / 22)$ & $70.12(54 / 77)$ & $72.27(73 / 101)$ \\
\hline Serositis & $50(1 / 2)$ & $18.18(4 / 22)$ & $9.09(7 / 77)$ & $11.88(12 / 101)$ \\
\hline - Pericardial effusion & $0(0 / 2)$ & $13.63(3 / 22)$ & $7.79(6 / 77)$ & $8.91(9 / 101)$ \\
\hline - Pleural effusion & $50(1 / 2)$ & $9.09(2 / 22)$ & $6.49(5 / 77)$ & $7.92(8 / 101)$ \\
\hline Renal disorder & $50(1 / 2)$ & $68.18(15 / 22)$ & $64.93(50 / 77)$ & $65.34(66 / 101)$ \\
\hline Neurologic disorder & $0(0 / 2)$ & $9.09(2 / 22)$ & $20.77(16 / 77)$ & $17.82(18 / 101)$ \\
\hline - Seizure & $0(0 / 2)$ & $9.09(2 / 22)$ & $15.58(12 / 77)$ & $13.86(14 / 101)$ \\
\hline - Psychosis & $0(0 / 2)$ & $0(0 / 22)$ & $9.09(7 / 77)$ & $6.93(7 / 101)$ \\
\hline \multicolumn{5}{|l|}{ Hematologic disorder } \\
\hline - Leukopenia & $50(1 / 2)$ & $40.90(9 / 22)$ & $44.15(34 / 77)$ & $43.56(44 / 101)$ \\
\hline - Thrombocytopenia & $0(0 / 2)$ & $9.09(2 / 22)$ & $18.18(14 / 77)$ & $15.84(16 / 101)$ \\
\hline \multicolumn{5}{|l|}{ Immunologic disorder } \\
\hline - Anti-DNA & $0(0 / 2)$ & $71.42(15 / 21)$ & $56.66(34 / 60)$ & $60.49(49 / 81)$ \\
\hline - Anti-Sm & $0(0 / 2)$ & $57.14(8 / 14)$ & $32.60(15 / 46)$ & $37.09(23 / 62)$ \\
\hline ANA & $100(2 / 2)$ & $100(22 / 22)$ & $98.68(75 / 76)$ & $99(99 / 100)$ \\
\hline - Homogenous pattern & $50(1 / 2)$ & $50(11 / 22)$ & $48.68(37 / 76)$ & $49(49 / 100)$ \\
\hline - Rim pattern & $0(0 / 2)$ & $40.90(9 / 22)$ & $44.73(34 / 76)$ & $33(33 / 100)$ \\
\hline - Nucleolar pattern & $0(0 / 2)$ & $0(0 / 22)$ & $3.94(3 / 76)$ & $3(3 / 100)$ \\
\hline - Speckle pattern & $50(1 / 2)$ & $45.45(10 / 22)$ & $59.21(45 / 76)$ & $56(56 / 100)$ \\
\hline
\end{tabular}

$\mathrm{ANA}=$ anti-nuclear antibodies; $\mathrm{bb}=$ excisable allele homozygote; $\mathrm{Bb}=$ heterozygote; $\mathrm{BB}=$ non-excisable allele homozygote; $\mathrm{SLE}$, systemic lupus erythematosus; $\mathrm{Sm}=$ Smith; VDR, vitamin D receptor. 
any association between VDR gene Bsml polymorphism and SLE. We further examined the relationship between VDR genotype and the individual clinical manifestation or laboratory profiles of SLE, which also cannot be statistically demonstrated.

\section{Conclusion}

It was apparent that compared with the genotype distribution of the VDR gene reported in previous studies [9-11], the genotype frequencies in Thais were different. Because our study includes a larger number of patients and controls than any previous study, we conclude that there is no association between VDR gene Bsml polymorphisms and SLE, at least in Thai patients. We propose that other VDR gene polymorphisms be examined.

\section{Competing interests}

The authors declare that they have no competing interests.

\section{Authors' contributions}

WS conceived of the study, and participated in its design, coordination and acquisition of data. OV carried out the molecular genetic study and performed statistical analysis. $\mathrm{KN}$ and KT participated in coordination and interpretation of data. PL participated in acquisition of data and helped in drafting and revising the manuscript. SJ have been involved in drafting and revising the manuscript for important intellectual content and have given final approval of the version to be published. All authors read and approved the final manuscript.

\section{Acknowledgements}

The work was supported by a grant from the Faculty of Medicine, Ramathibodi Hospital, Mahidol University, Bangkok, Thailand.

\section{References}

1. Tso BP: The genetics of human Lupus 6th edition. Philadelphia: Willium \& Wilkins; 2002

2. Lemire JM: Immunomodulatory role of 1,25-dihydroxyvitamin D3. J Cell Biochem 1992, 49:26-31.

3. Muller K, Kriegbaum NJ, Baslund B, Sorensen $\mathrm{OH}$, Thymann M, Bentzen K: Vitamin D3 metabolism in patients with rheumatic diseases: low serum levels of 25-hydroxyvitamin D3 in patients with systemic lupus erythematosus. Clin Rheumatol 1995, 14:397-400.

4. Huckins D, Felson DT, Holick M: Treatment of psoriatic arthritis with oral 1,25-dihydroxyvitamin D3: a pilot study. Arthritis Rheum 1990, 33:1723-1727.

5. Andjelkovic Z, Vojinovic J, Pejnovic N, Popovic M, Dujic A, Mitrovic $D$, Pavlica L, Stefanovic D: Disease modifying and immunomodulatory effects of high dose 1 alpha $(\mathrm{OH})$ D3 in rheumatoid arthritis patients. Clin Exp Rheumatol 1999, 17:453-456.

6. Eisman JA: Genetics of osteoporosis. Endocr Rev 1999, 20:788-804.

7. Carling T, Rastad J, Akerstrom G, Westin G: Vitamin D receptor (VDR) and parathyroid hormone messenger ribonucleic acid levels correspond to polymorphic VDR alleles in human parathyroid tumors. J Clin Endocrinol Metab 1998, 83:2255-2259.

8. Ingles SA, Coetzee GA, Ross RK, Henderson BE, Kolonel LN, Crocitto L, Wang W, Haile RW: Association of prostate cancer with vitamin D receptor haplotypes in African-Americans. Cancer Res 1998, 58:1620-1623.

9. Ozaki Y, Nomura S, Nagahama M, Yoshimura C, Kagawa H, Fukuhara S: Vitamin-D receptor genotype and renal disorder in Jap- anese patients with systemic lupus erythematosus. Nephron 2000, 85:86-91.

10. Huang $\mathrm{CM}, \mathrm{Wu} \mathrm{MC}, \mathrm{Wu}$ JY, Tsai FJ: Association of vitamin D receptor gene Bsml polymorphisms in Chinese patients with systemic lupus erythematosus. Lupus 2002, 11:31-34.

11. Huang CM, Wu MC, Wu JY, Tsai FJ: No association of vitamin D receptor gene start codon fok 1 polymorphisms in Chinese patients with systemic lupus erythematosus. I Rheumatol 2002, 29:1211-1213.

12. Tan EM, Cohen AS, Fries JF, Masi AT, McShane DJ, Rothfield NF, Schaller JG, Talal N, Winchester RJ: The 1982 revised criteria for the classification of systemic lupus erythematosus. Arthritis Rheum 1982, 25:1271-1277.

13. Holick MF: Vitamin D: importance in the prevention of cancers, type 1 diabetes, heart disease, and osteoporosis. Am J Clin Nutr 2004, 79:362-371.

14. Malluche $\mathrm{HH}$, Mawad $\mathrm{H}$, Koszewski NJ: Update on vitamin D and its newer analogues: actions and rationale for treatment in chronic renal failure. Kidney Int 2002, 62:367-374.

15. Lemire JM, Adams JS, Kermani-Arab V, Bakke AC, Sakai R, Jordan SC: 1,25-Dihydroxyvitamin D3 suppresses human T helper/ inducer lymphocyte activity in vitro. J Immunol 1985, 134:3032-3035.

16. Bhalla AK, Amento EP, Krane SM: Differential effects of 1,25dihydroxyvitamin D3 on human lymphocytes and monocyte/ macrophages: inhibition of interleukin-2 and augmentation of interleukin-1 production. Cell Immunol 1986, 98:311-322.

17. Lemire JM, Archer DC, Beck L, Spiegeburg HL: Immunosuppressive actions of 1, 25-Dihydroxyvitamin D3: Preferential inhibition of Th1 functions. J Nutr 1995, 125:1704S-1708S.

18. Reichel $H$, Koeffler HP, Tobler A, Norman AW: 1 alpha,25-Dihydroxyvitamin D3 inhibits gamma-interferon synthesis by normal human peripheral blood lymphocytes. Proc Natl Acad Sci USA 1987, 84:3385-3389.

19. Iho S, Takahashi T, Kura F, Sugiyama H, Hoshino T: The effect of 1,25-dihydroxyvitamin D3 on in vitro immunoglobulin production in human B cells. J Immunol 1986, 136:4427-4431.

20. Peacock M, Turner CH, Econs MJ, Foroud T: Genetics of osteoporosis. Endocr Rev 2002, 23:303-326.

21. Voll RE, Roth EA, Girkontaite I, Fehr H, Herrmann M, Lorenz HM, Kalden JR: Histone-specific Th0 and Th1 clones derived from systemic lupus erythematosus patients induce doublestranded DNA antibody production. Arthritis Rheum 1997, 40:2162-2171.

22. Tsokos GC, Boumpas DT, Smith PL, Djeu JY, Balow JE, Rook AH: Deficient gamma-interferon production in patients with systemic lupus erythematosus. Arthritis Rheum 1986, 29:1210-1215.

23. Kelley VR, Wuthrich RP: Cytokines in the pathogenesis of systemic lupus erythematosus. Semin Nephrol 1999, 19:57-66.

24. Ongphiphadhanakul B, Rajatanavin R, Chanprasertyothin S, Chailurkit L, Piaseu N, Teerarungsikul K, Sirisriro R, Komindr S, Puavilai $G$ : Vitamin D receptor gene polymorphism is associated with urinary calcium excretion but not with bone mineral density in postmenopausal women. J Endocrinol Invest 1997, 20:592-596. 